\title{
A Report on the Screendance Symposium
}

\author{
University of Brighton, February 4, 2011
}

Claudia Kappenberg and Sarah Whatley

I February of this year, the International Screendance Network hosted a symposium at the University of Brighton, UK to mark the conclusion of a two-year research period. Funded by a Network Grant from the Arts and Humanities Research Council (UK) the Screendance Network was established in 2009 in order to accelerate the discourse and publication in screendance. The group, composed of three American and five UK-based scholars and artists, is led by Claudia Kappenberg (Principal Investigator, School of Arts and Media, University of Brighton) and Sarah Whatley (Co-Investigator, Coventry University). Since its inception the Network has met four times: in Brighton (September 2009), Coventry (January 2010), Durham, North Carolina (June 2010) and again in Brighton (February 2011). During these seminars the group exchanged research interests, explored possible strategies for dissemination and established the new International Journal of Screendance.

The aim of the symposium was to meet with a larger research community, to encourage participation from younger researchers with interests in screendance, to disseminate the work of the Screendance Network, and to invite guest speakers from related fields of practice in order to expand the parameters of the debates. Kappenberg and Whatley introduced the day by summarizing the developments of the last five years and inviting everyone to consider that "Screendance had not yet been invented," a motto which is also featured on the cover of the first issue of the International Journal of Screendance.

The invited speakers were CatherineWood, Curator Contemporary Art and Performance (Tate Modern), Choreographer Siobhan Davies and filmmaker David Hinton. Responses to historical theoretical texts were given by filmmaker Miranda Pennell (UK) and Network member and dance scholar Ann Cooper Albright (Oberlin College, Ohio US). Following the presentations audiences debated various topics using the Open Space format, sharing findings in a final plenary session.

The speakers were able to raise important questions about how screendance is "read" and critiqued within different frameworks. 


\section{Screendance Symposium}

Friday, February 4, 2011

Sallis Benney Theatre

University of Brighton

Grand Parade BN2 OJY

\section{Perspectives in Screendance}

\section{SCHEDULE}

Symposium 10:00 am - 6:00 pm

\section{9:30 am Registration}

10:00 am Claudia Kappenberg/ Sarah Whatley: Welcome and Introduction

10:15 am Session1: A Curatorial Perspective

Ballet Mecanique, presentation and screening by Catherine Wood,

Curator Contemporary Art and Performance at Tate Modern

11:30 am Coffee

Noon Session 2: A Choreographic Perspective

Choreographer Siobhan Davies and Filmmaker

David Hinton discuss a new project

1:00 pm Lunch buffet

2:00 pm Session 3: A Theoretical Perspective

Filmmaker Miranda Pennell and dance scholar Ann Cooper Albright

(Screendance Network) comment on historical theoretical texts.

3:00 pm Open Space Debate

A discussion with all delegates using the Open Space format

followed by Plenary Session with the Screendance Network

Dinner and Screening 6:30 - 9:00 pm

6:30 pm Dinner: University of Brighton canteen

8:00 pm Screening: Works by Catherine Long,

Lizzie Sykes, Becky Edmunds, Jérôme Bel 


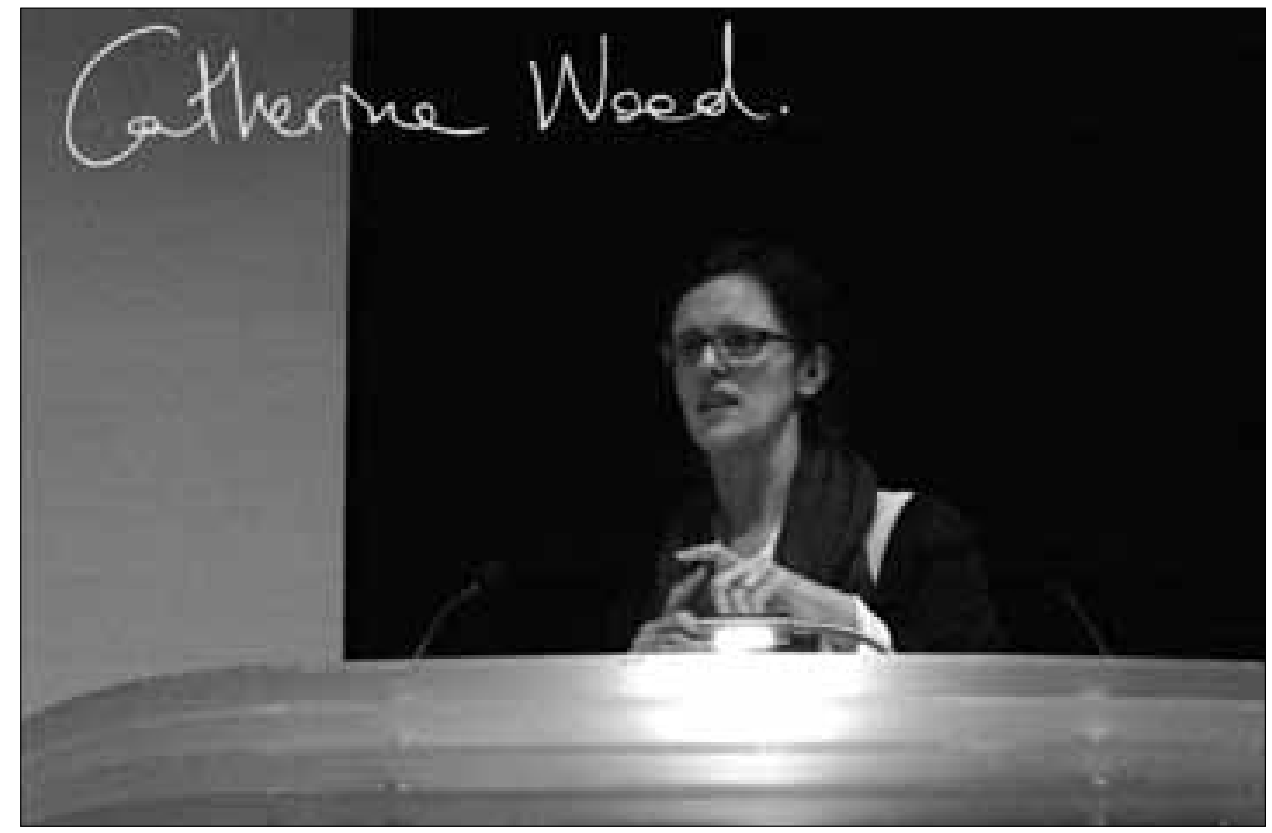

Catherine Wood, Curator Contemporary Art and Performance (Tate Modern)

Catherine Wood used the symposium as an opportunity to explore ideas about performance in the everyday as always already mediated, asking where screendance today begins or ends. She discussed the work of visual artists Dara Birnbaum, Mark Leckey, Bonnie Camplin, Catherine Sullivan, and Keren Cytter as examples of how contemporary artists are responding to the increasing pervasiveness of media technology in the everyday. She argued that since the mid-seventies appearances and behaviour are more and more geared towards screen performance and that this in turn affects contemporary choreographic and cinematographic processes. Her insightful readings offered delegates tools for reading and responding to a range of work that had not previously been debated within the context of screendance.

As independent curator and writer Helena Blaker commented, Catherine Wood was using the opportunity of this forum to "test" her ideas about performance (as now always an internal image, in a highly mediated context); and to explore this as an alternative critical frame for the work of visual artists whose projects she had previously seen in a different light. For Helena Blaker, this was "a good start to the day with a new theoretical position that was in the process of being tested, specifically for this context and because of the provocations (towards a new viewpoint) created by screendance."

CW:The now ubiquitous presence of screen-based technology opens up the capacity for a significant shift in how dance on screen can be thought about-and even dance beyond screen in everyday life.

CW: Passages of our daily movement are constantly being captured, recorded, replayed and embedded in a whole other meta-level of choreography of moving images, which is part of the everyday fabric. 


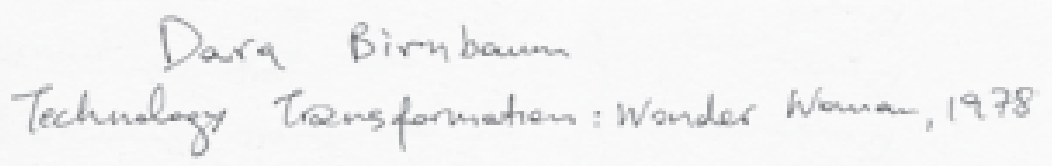

CW: Dara Birnbaum's work represents a key step in understanding the way that this kind of choreography of gesture via film and television, and now other new media, plays a part in how we might understand ordinary movement today.

\section{Delegate \\ Marina Tsartsara}

CW: How do we reverse the terms of the all-pervasive image world and demand that it be lumpy, graspable and awkward? instead of being forced to aspire to its flatness?

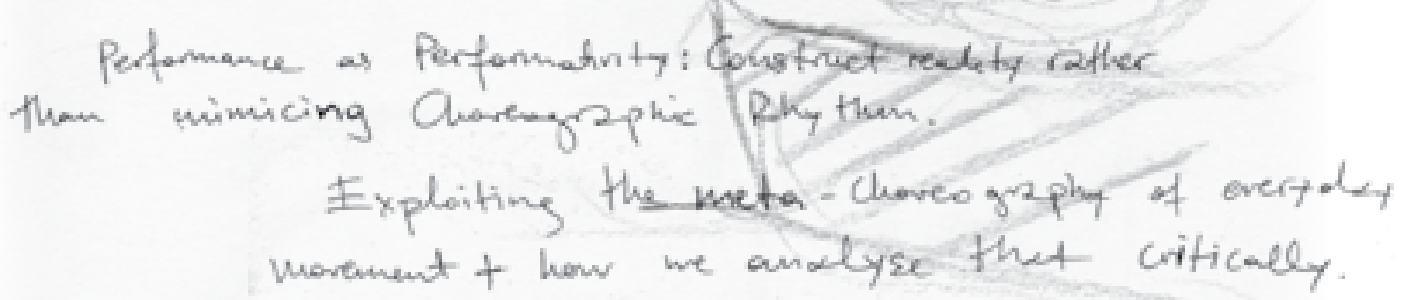

CW: A conflation of the languages of dance and film is what necessarily constitutes this new language. One is simultaneously factual and symbolic and proposes a different kind of blurring between art and life.

CW: Does screendance replace what was thought to be ordinary dance in the sixties, that is, an incorporation of another level of mediated movement into our experience of the everyday here and now? ... I suppose I was thinking about where does screendance end and non-screendance begin and how easy is it to draw that distinction? 


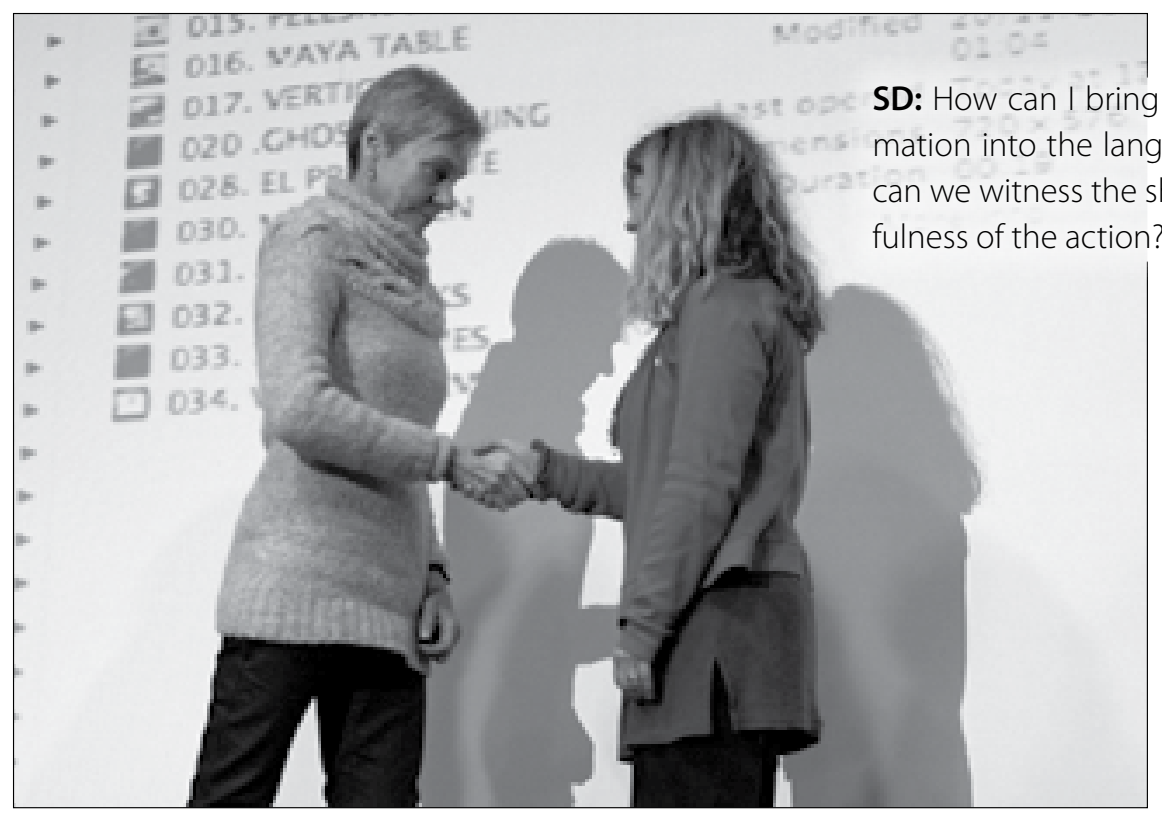

Choreographer Siobhan Davies and filmmaker David Hinton shared a conversation about a forthcoming screendance collaboration, discussing their creative processes and interests in how they think they might be working together. As an established choreographer, Davies is curious about how the detail and particularity of the dancing body can move from a live space to a screen, and how that will inform and shift her thinking about dance. Hinton showed examples of work that demonstrated a cinematic aesthetic and reflected on aesthetic differences between live and mediated work.

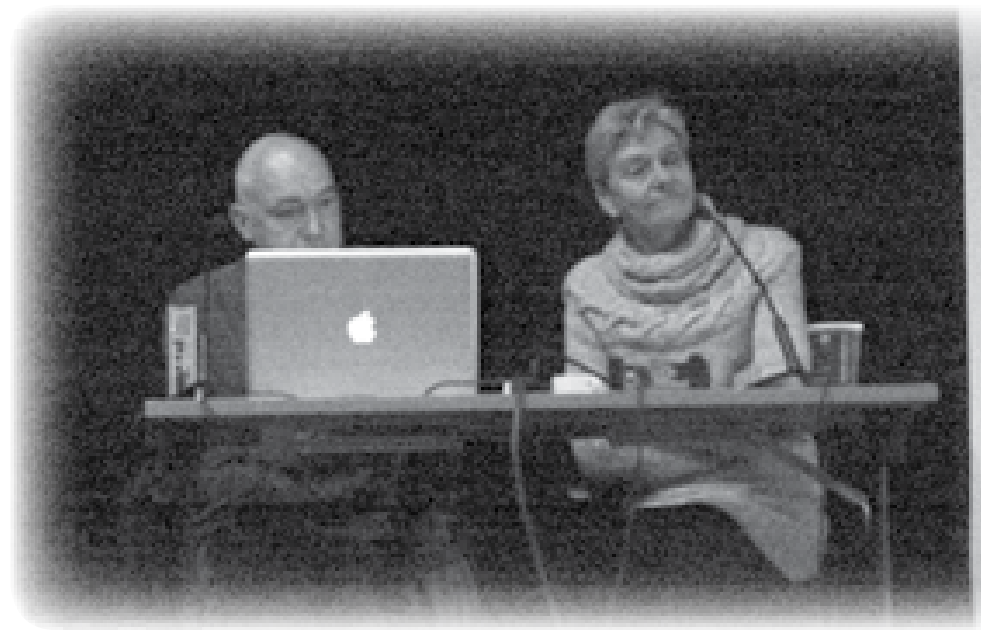

DH: Is the image of the walk interesting? I have an instinct immediately to dramatize the walk...

SD: And I have an immediate instinct to orchestrate the walk... The walk is this massive amount of information-probably about 1000 activities in the body which allow us to walk. 
A Report on the Screendance Symposium University of Brighton, February 4, 2011

145

To think the Image of a Wake; * To fiericaley think the Image of a

The orchestration of a walk $\rightarrow$ walking as a means of "embodying" the work $\alpha$.

The process of oisgantuing an action: $\rightarrow$ glimpse into the non linearity of thought

I thine about chance implication within gyrapty as a latent various parametersorinay actions; the choreography of which imply a the cheaply of sorts. To dismantle chomegrafy of ordinance is to lategraph a dance that is always possible always potential: it becomes risibly possible through interruption, through formal e. appropriation, through the process of being distant $4 \alpha$. of the performed action int the soleure $\alpha$ "transposition") Delegate Elinor Cleghorn (PhD candidate, London Consortium) 
Miranda Pennell and Anne Cooper Albright shared reflections on established theoretical texts which have been selected by the Screendance Network as providing a potential scaffolding for thinking and writing about screendance. Pennell discussed Laura Mulvey's essay, "The Pensive Spectator," exploring the choreographic potential of the still image to animate the inanimate and with respect to her own work.['] Albright sketched key ideas of Heidegger's seminal essay, "The Question Concerning Technology," exploring the etymological root, techne, as signifying both skill and a process of revealing whilst linking techne to episteme, a way of knowing the world. [2] Albright invited delegates to review the relation between dance techniques and media technologies, arguing that we are inevitably and irrevocably changed when "captured" and "processed" by imaging technologies and that screendance describes precisely this tension between embodiment and technology.

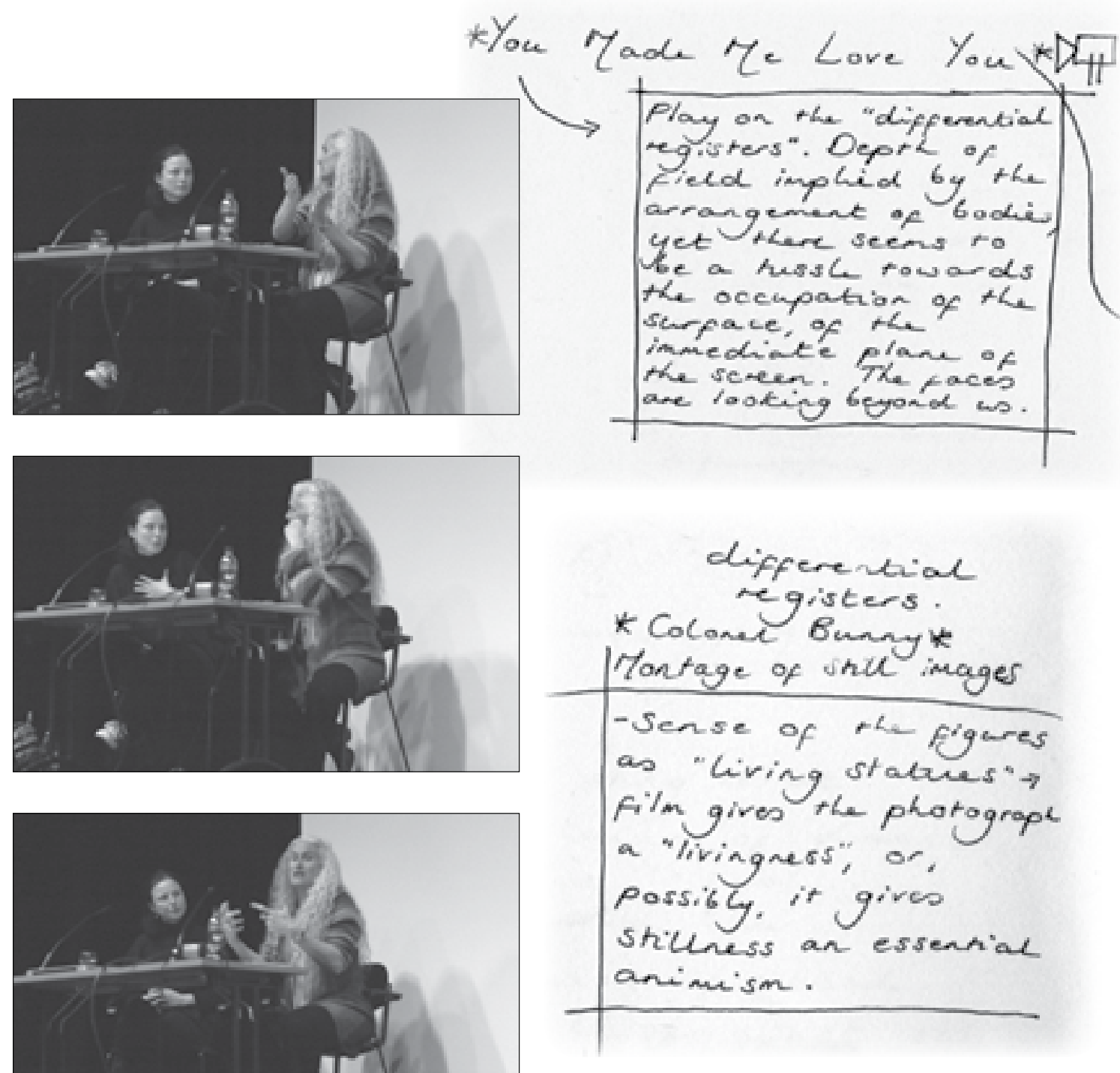

Delegate Elinor Cleghorn 
* Miranda imimes" the action of serocking through, rolling through, footage in pwrwit of the initial interest in the scene. A double thanded gesture: thes suggests the technology implies a sort of rehoregroptic: moductation of +L $60 \%$.

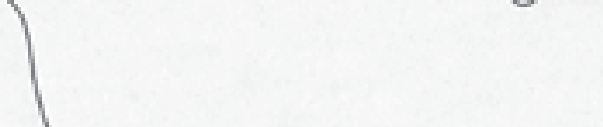

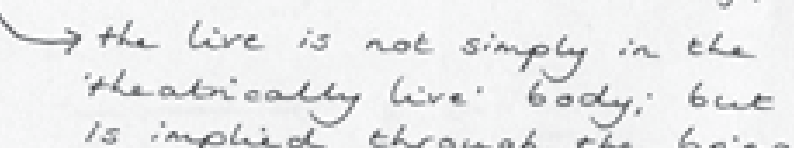
Is implied through the bringing out of content and re presenting of an object in cinema that can lend it a cinematicaly specific "Live" quality.

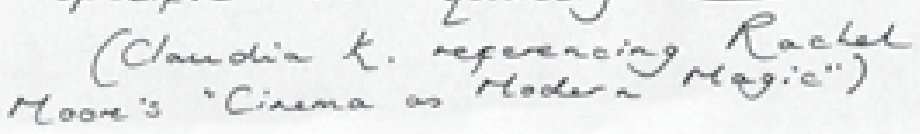

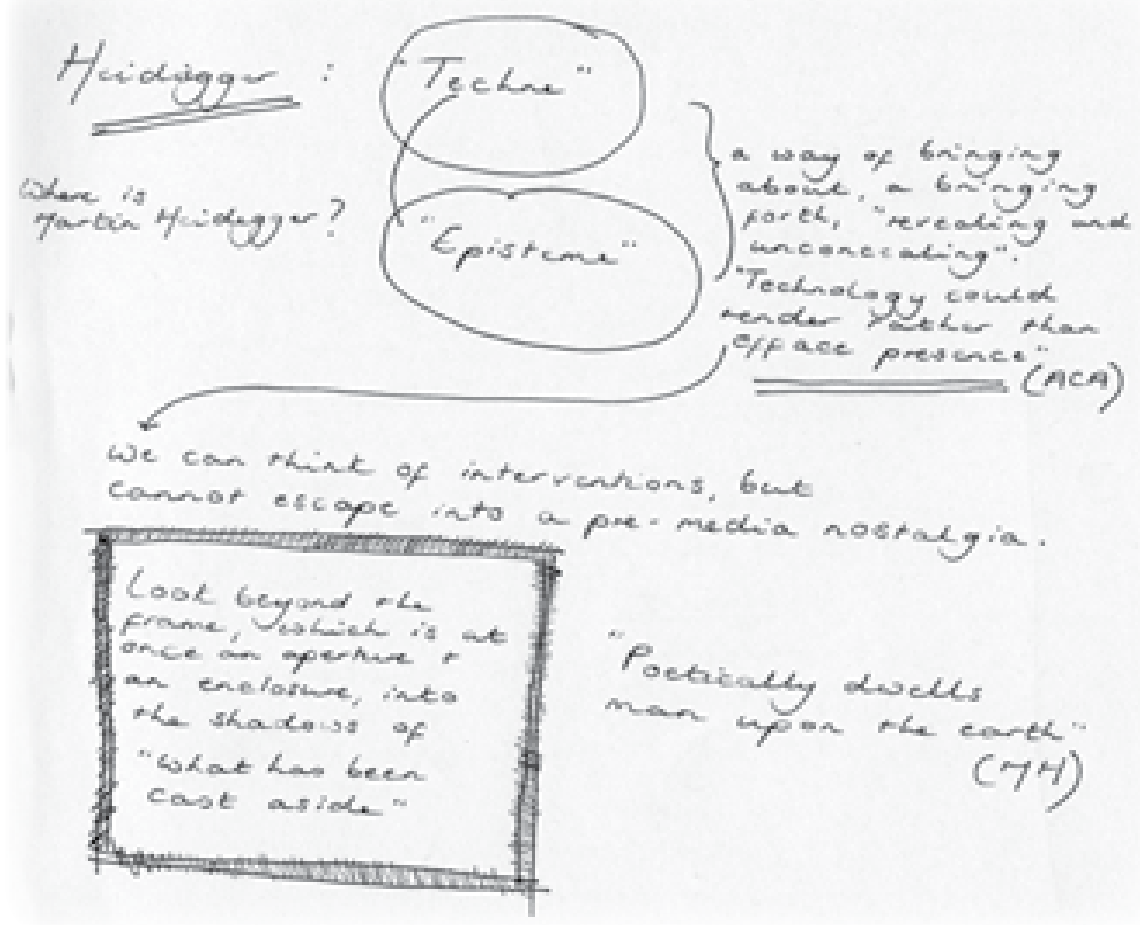


Delegate Karen Wood (PhD candidate, researching kinaesthetic empathy and screendance audiences at the University of Manchester) noted how both speakers raised an important

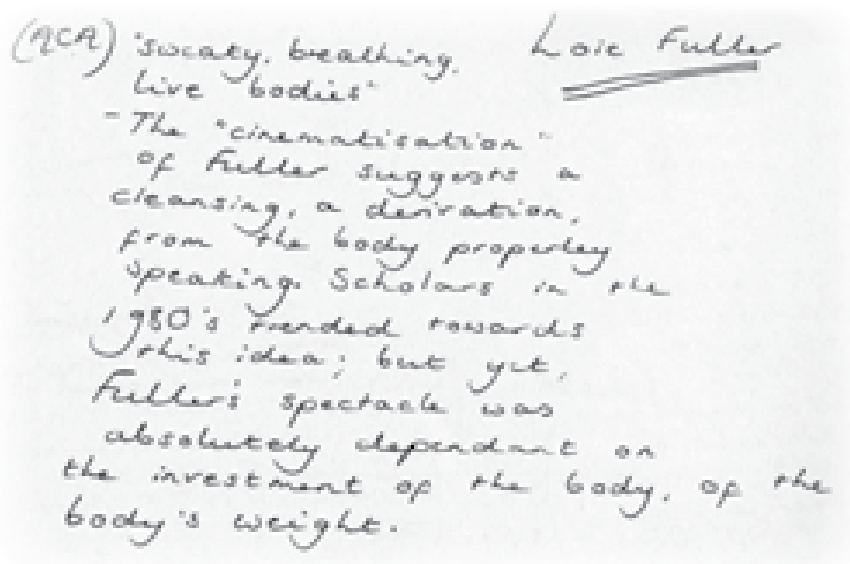

Delegate Elinor Cleghorn point in how our relationship with time is changing with digital technologies and "how this could open screendance up to creative, imaginative possibilities." She also noted that "the practice may need to realign its current thinking, in light of new technologies, to extend further to a larger audience."

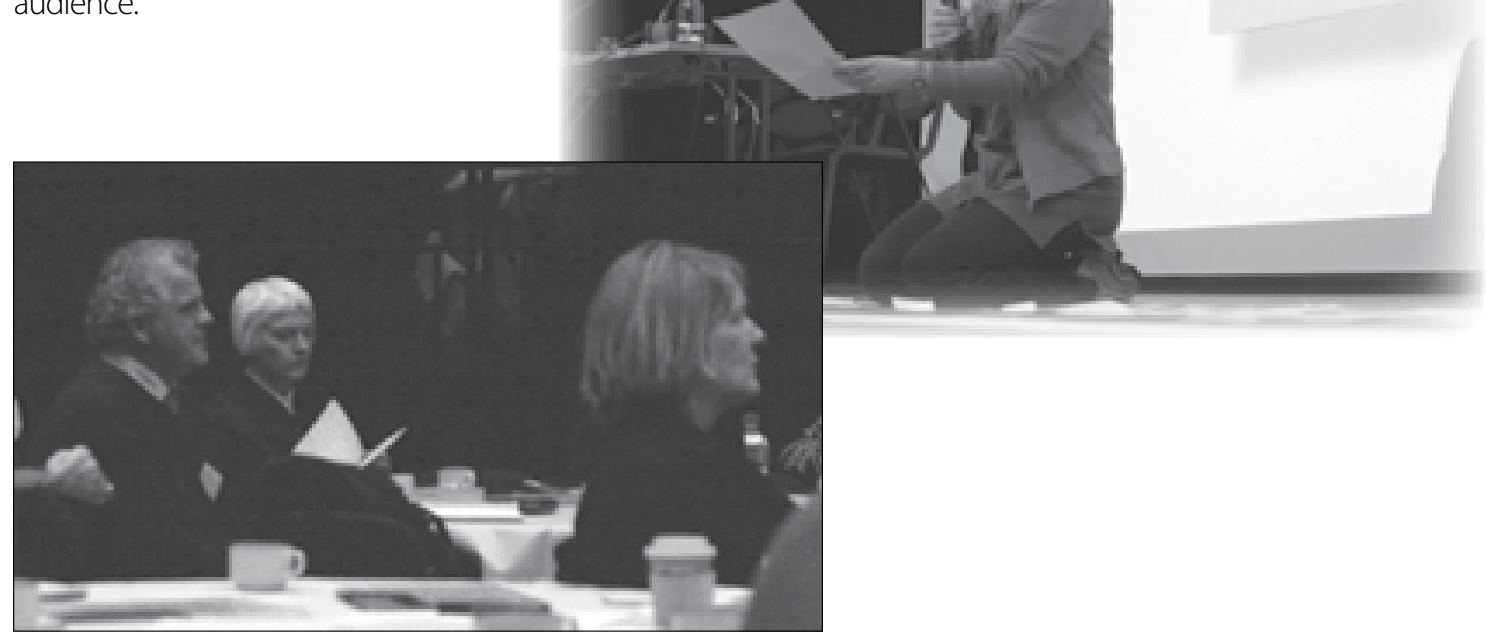

The presentations were followed by an Open Space debate, which was chaired by Sarah Whatley. Delegate Helena Blaker commented on the productive and political nature of the discussion. Her group explored "how far the mechanism of the screen can become a social/political catalyst for the re-envisioning of the position of the body in society." Other groups reflected on what kind of liveness is brought about by screen performance and how mediation complicates notions of fiction and reality, documentation, authenticity and stillness within the moving image. 

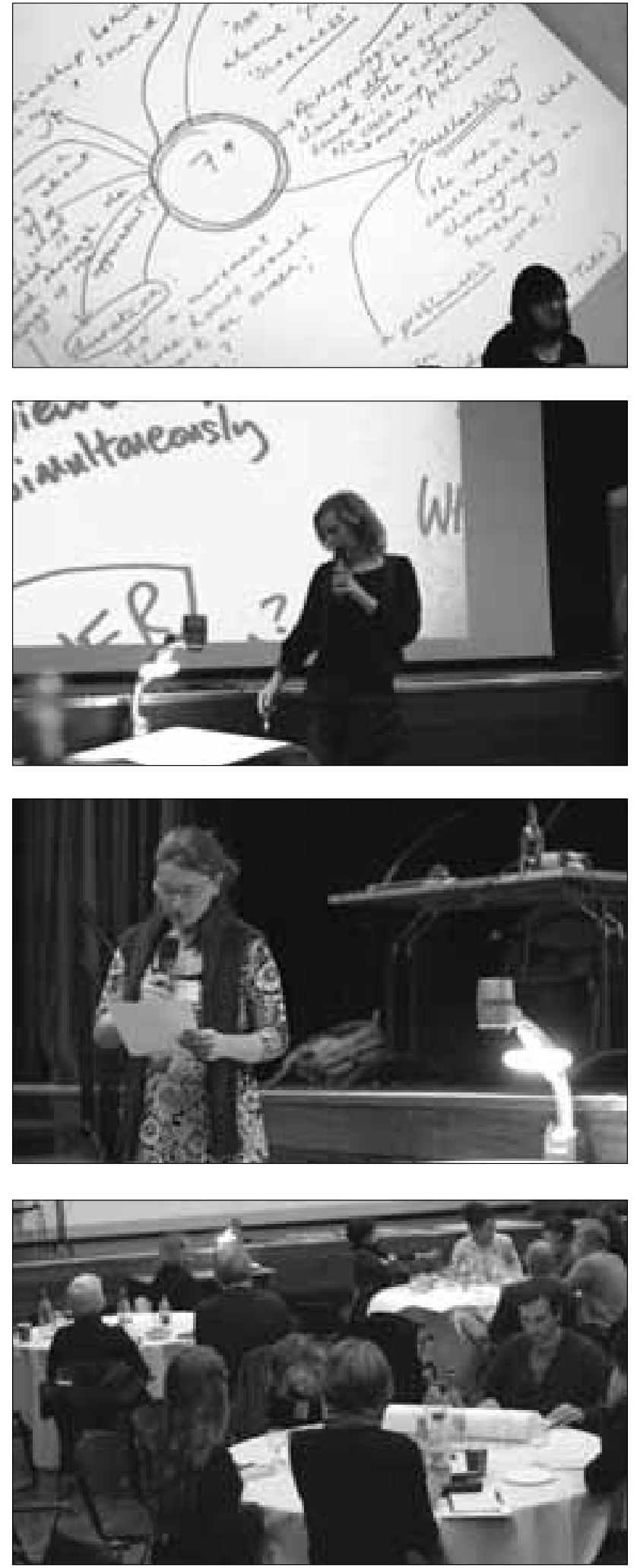

Mariana Pimentel, one of the overseas delegates from Brazil and currently working in Lisbon, Portugal, talked enthusiastically about the Symposium ad echoed a question that was raised during the Open Space discussion: "Is screendance an interdisciplinary practice, a hybrid practice or does it generate its own form and language?"

"The discussion and group exercises were both effective and appropriate to the unfolding of the day. I often find such exercises ineffectual and to some degree tokenistic; however in this case they were indeed highly productive, particularly in engaging the views of the ,Äòdance film community, if one were to recognise such a group. I hope this Network continues to evolve." (Nic Sandiland, screendance artist and senior lecturer at Middlesex University)

Mary Wycherley, a practitioner and lecturer in multi-disciplinary performance practice, somatics and screendance in Limerick, Ireland said that she appreciated "the weight of interest in and distinct relationship between screendance and Video Art." She also pointed out that delegates shared "interest in both the practical development and the theoretical frameworks involved in the process of making screen-based work" and she was "impressed by the representation of different countries" at the symposium which felt significant for the cross-fertilization in the dialogue. 
After a communal dinner the day concluded with a screening, which had been curated by Professor Liz Aggiss (School of Arts and Media, University of Brighton) and Claudia Kappenberg. The screening began with a series of shorts by artists from the South East; Catherine Long, Lizzie Sykes and Becky Edmunds, in which the actual physical processes of filming and framing determine the choreography, thereby challenging traditional hierarchies of filmmaking and choreographing.

The shorts were followed by French Choreographer Jérôme Bel's epic Véronique Doisneau, a work made in 2004 during a residency at the Paris Opera. Much of Bel's oeuvre inverts hierarchies within theatrical traditions and in this work a single ballerina from a traditional corps de ballet becomes the sole star of the show, dancing excerpts of her subsidiary roles against the absence of the company and its soloists.
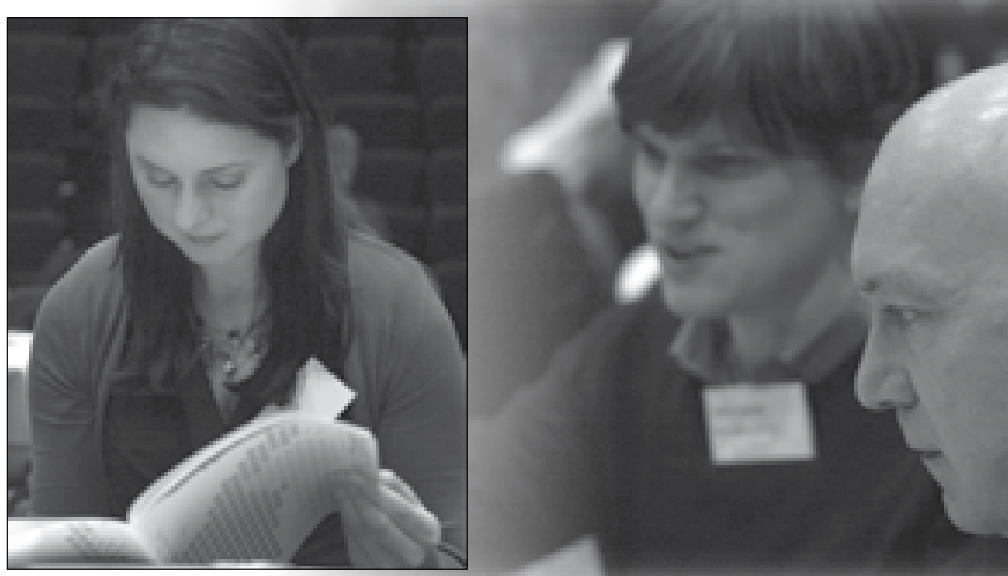

\section{SCREENING}

Catherine Long, Experiment. Number 1 2010, 2 mins. 30 sec.

Lizzie Sykes, Angry Rambler 2005, 1 min. $15 \mathrm{sec}$.

Lizzie Sykes, Tiago's Sequence 2005, 2 mins. 5 sec.

Becky Edmunds, Skate 2009, 4 mins. 40 sec.

Becky Edmunds, stand in 2009, 5 mins.

Jérôme Bel, Véronique Doisneau 2004, 37 mins.

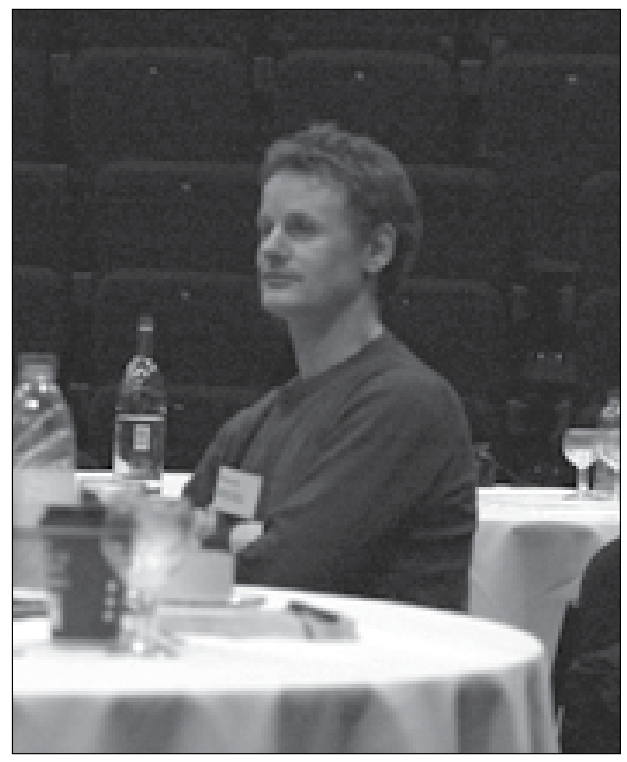




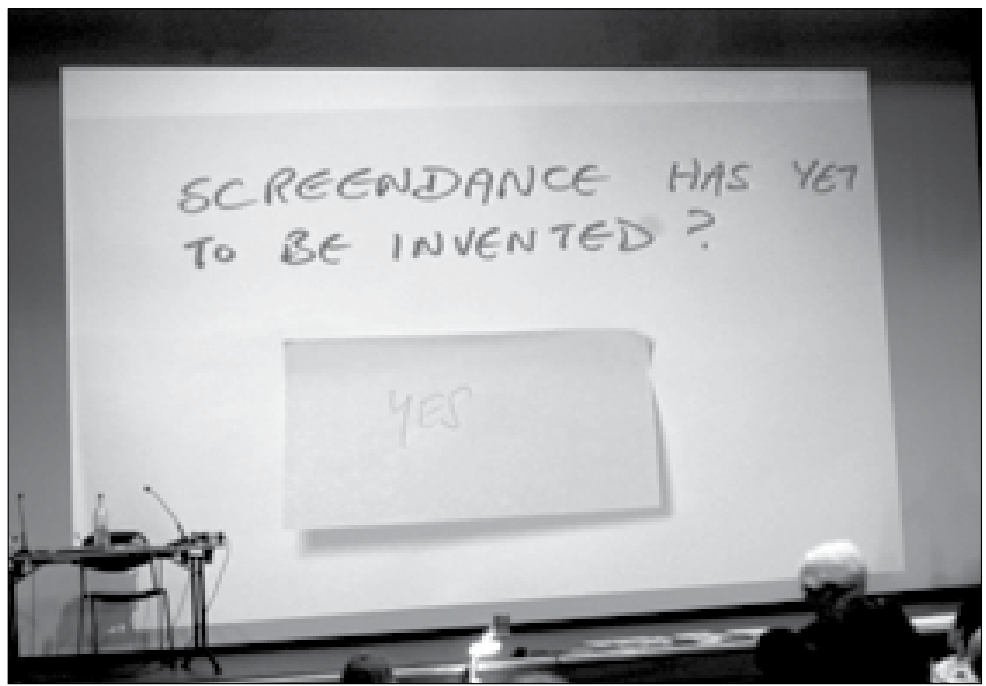

"We were knights at round tables with pristine tablecloths. We charged our minds and thoughts and drifted into personal frames to find the frame. Screen dance is yet to be invented?

Do we agree? Do l agree?
"... So we segued from Wonder Woman to Leger, from Fiorrucci made me Hardcore to Parade, from Get me a Mirror to Man Ray, and we thought to move and moved to think and crossed high bridges, dismantled actions, watched sheep pour down slopes of shale, and unpicked the edit and the reasons to be cheerful. Sites were resighted, relocated and retasked. We tossed off all the Bs, Barthes, Bourriaud, and Benjamin and sped off to embalm life with photographs, mummifying the living with our cut ups, stilled stop frames and stasis. Is performance 'nowness'? Is film and photo 'thenness'? You Made Me Love You said Miranda in Capitals, and we did. Screendance is a priority of agency and access to technology. Why did I write that? Time to see some screendance without the dance that we expect. Tossed cameras skating on thin ice if you please, a women running with Baudrillard in mind, it's in your head I am shouting, it's all in your head, angry walkers and fish eye lenses and nothing makes sense any more, the world has inverted, gone Dutch and I felt sick. Then I had a happy moment with Véronique Doisneau just too too so so française and then I had one red wine too much and got edited out." (Professor Liz Aggiss, Performance and Visual Art, University of Brighton)

Delegate David McCormick (filmmaker and Senior lecturer in Screendance at the University of Winchester) commented that through the International Journal of Screendance an articulation of its presence as an evolving art form has been achieved.

\section{Credits:}

Scribe (scribbles): Elinor Cleghorn

Scribe (drawings): Marina Tsartsara

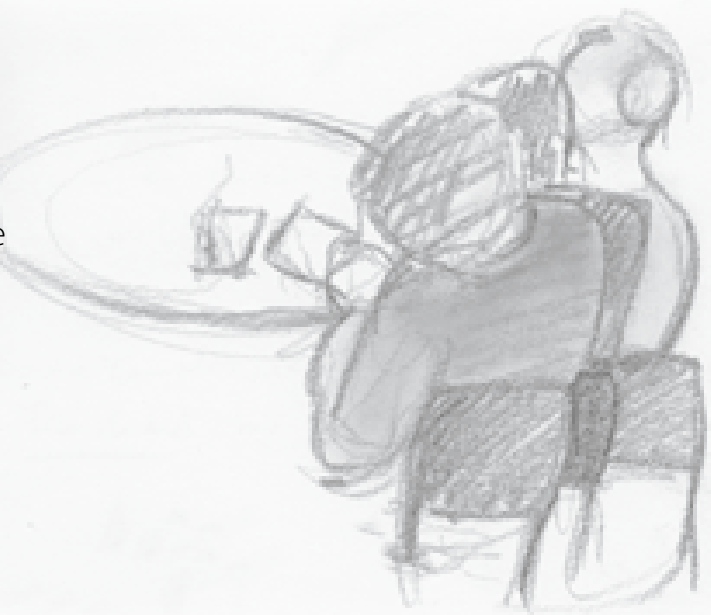




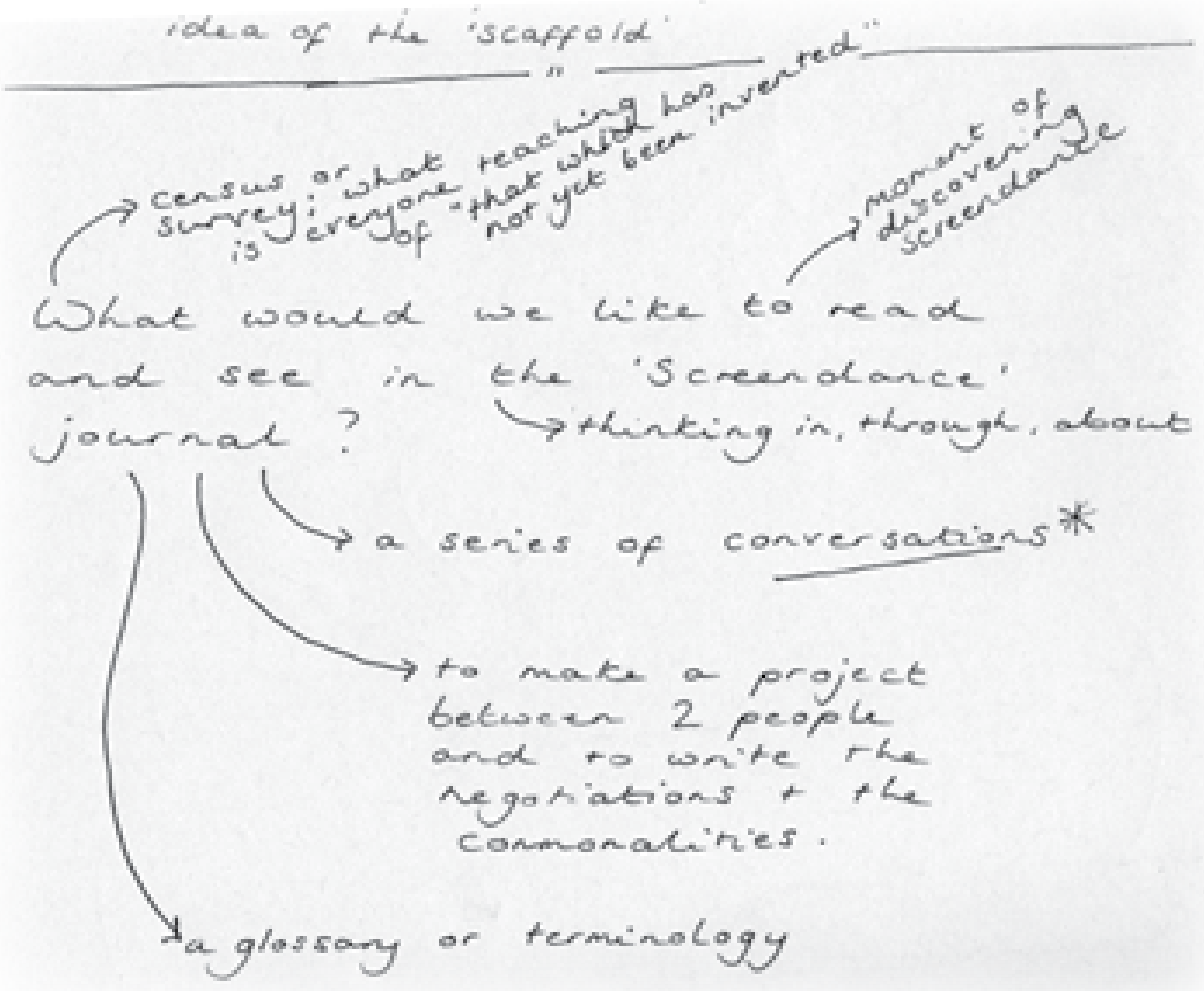

\section{References}

Mulvey, Laura. Death 24xper Second: stillness and the moving image. London: Reaktion Books, 2006.

Heidegger, Martin. The Question Concerning Technology and Other Essays. Translated by W. Lovitt. New York: Harper Torchbooks, 1977.

\section{Notes}

1. Mulvey, Death 24x per Second: stillness and the moving image. Pennell's presentation is printed in full elsewhere in this issue.

2. Heidegger, The Question Concerning Technology and Other Essays.

Albright's paper is also printed in full elsewhere in this issue.

\section{Dear Journal Reader:}

We would also like to ask you: what would you like to read or see in the International Journal of Screendance? Perhaps you have a question you would like to see discussed, or you know someone who we could invite to write for the Journal? Perhaps you have read a book that you think should be reviewed?

Please email any suggestions or comments to the editors:

Claudia Kappenberg

C.Kappenberg@ brighton.ac.uk Douglas Rosenberg rosend @ education.wisc.edu 